\title{
Building a green economy of low carbon: the Greek post-crisis experience of photovoltaics and financial 'green grabbing'
}

\author{
Zoi Christina Siamanta ${ }^{1}$ \\ Birkbeck College, University of London, UK
}

\begin{abstract}
Under the global rhetoric of 'the green economy' Renewable Energy Resources (RES) projects have proliferated across the world. This article examines the growth of photovoltaic projects in post-crisis Greece, grounded in a green energy discourse. The aim is to provide insights into how green economies are built and what new appropriations they (might) entail. It is based on a Foucauldian oriented discourse analysis, in depth semi-structured interviews and review of a variety of other sources. The article argues that justificatory discourses for green growth implicated in 'green grabbing' involve the complex interplay of neoliberal and disciplinary 'environmentalities.' These seek to construct 'green economy' entrepreneurs and compliant subjects. A relatively undocumented and understudied aspect of green grabs is the appropriation of public and private financial resources for photovoltaic projects, with significant negative impacts on livelihoods. In Greece, this has resulted in the accumulation of capital by a few large RES companies, as well as significant impacts on the livelihoods of domestic and small business electricity consumers and small/medium photovoltaic investors through debt.
\end{abstract}

Key words: Greece, green economy, photovoltaics, green grabbing, environmentality, Foucault, green energy

\section{Résumé}

Dans le cadre de la rhétorique mondiale de l'économie verte, les projets de ressources énergétiques renouvelables (RSE) ont proliféré à travers le monde. Cet article examine la croissance des projets photovoltaïques dans la Grèce post-crise, fondée sur un discours sur l'énergie verte. L'objectif est de donner un aperçu de la façon dont les économies vertes sont construites et de quels nouveaux crédits ils (pourraient) impliquer. Il est basé sur une analyse du discours orienté Foucauldien, des entretiens semi-structurés en profondeur et l'examen d'une variété d'autres sources. L'article soutient que la justification de «l'accaparement vert» et de la «croissance verte» implique l'interaction des «environnementalités» néolibérales et disciplinaires. Ceux-ci cherchent à construire «économie verte» des entrepreneurs et des sujets conformes. Un aspect relativement non documenté et peu étudié est l'appropriation des ressources financières publiques et privées pour les projets photovoltaïques, avec des impacts significatifs sur les moyens de subsistance. En Grèce, cela s'est traduit par l'accumulation de capitaux par quelques grandes entreprises de FER et par des impacts significatifs pour les ménages et les petites entreprises ainsi que pour les petits et moyens investisseurs photovoltaïques.

Mots-clés: Grèce, économie verte, photovoltaïque, accaparement vert, environnementalité, Foucault, énergie verte

\section{Resumen}

Bajo una retórica de "la economía verde", proyectos de Recursos de Energía Renovable (RER) han proliferado en el mundo. Este artículo examina el crecimiento de proyectos fotovoltaicos en Grecia post-crisis basados en un discurso de energía verde. El objetivo es aportar nociones de cómo las economías verdes están construidas y qué nuevas apropiaciones (pueden) implicar. Se basa en los hallazgos derivados de un análisis del discurso con orientación foucaultiana de entrevistas a profundidad semi estructuradas, así como la revisión de una variedad de otras fuentes de información. El artículo argumenta que los discursos justificatorios del crecimiento verde implicados en la "apropiación verde", involucran una compleja articulación de

\footnotetext{
${ }^{1}$ Dr. Zoi Christina Siamanta, Birkbeck College, University of London, UK. Email: christina.siamanta "at" gmail.com. Acknowledgements: many thanks to the Special Section organizers and to Sian Sullivan and two reviewers for comments on the manuscript. This is the third article in Connor Cavanagh and Tor Benjaminsen (eds.) 2017."Political ecologies of the green economy", Special Section of the Journal of Political Ecology, 24:200-341.
} 
"ambientalidades" neoliberales y disciplinarias en la búsqueda de construir empresarios y sujetos conformes, ambos de "economía verde". El artículo también argumenta un relativamente poco estudiado y documentado pero importante - aspecto de las apropiaciones verdes: la apropiación de los recursos financieros públicos y privados, y sus importantes impactos en las formas de subsistencia. En el caso griego, las apropiaciones verdes a través de los proyectos fotovoltaicos han resultado en la acumulación de capital de unas cuantas grandes compañías RER, así como importantes impactos en las formas de subsistir de negocios locales pequeños consumidores de energía, así como en pequeños y medianos inversionistas fotovoltaicos.

Palabras clave: Grecia, economía verde, fotovoltaicos, apropiación verde, ambientalismo, Foucault, energía verde

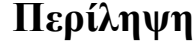

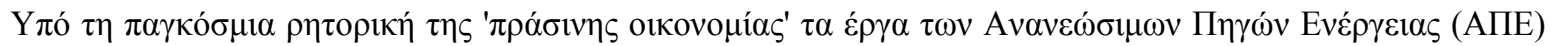

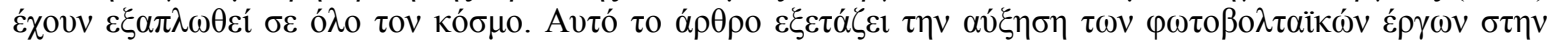

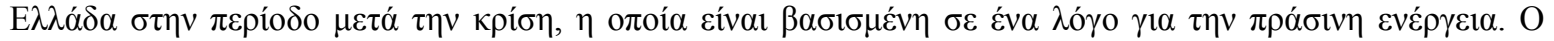

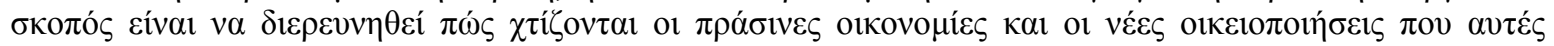

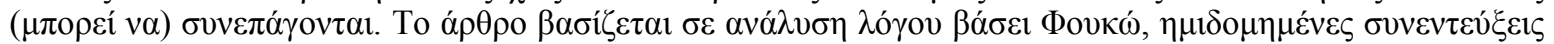

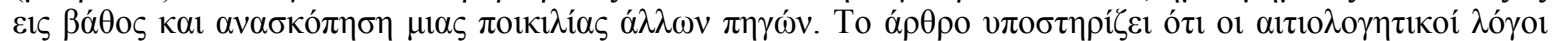

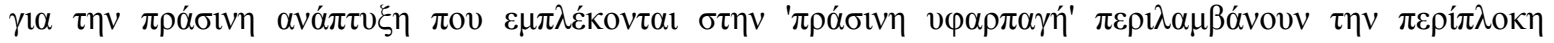

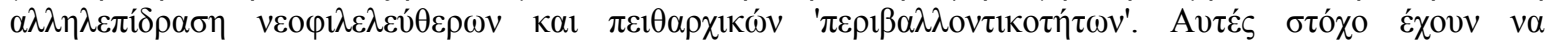

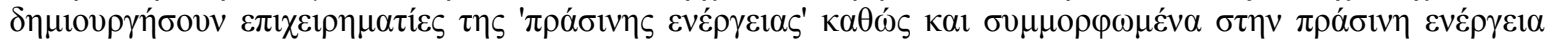

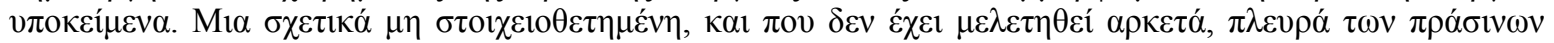

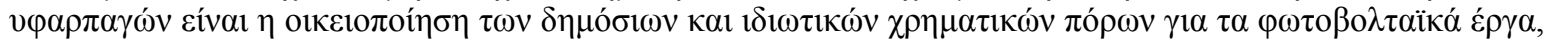

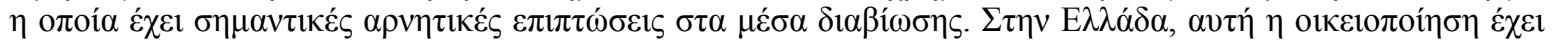

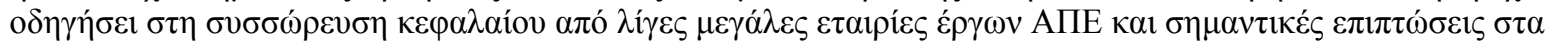

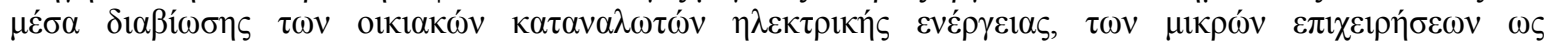

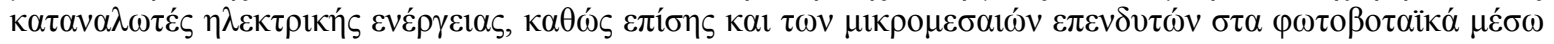

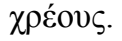

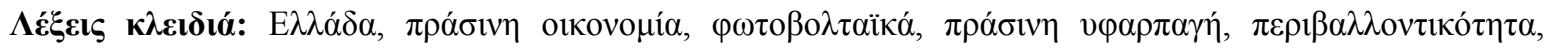

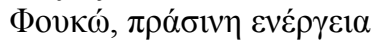

\section{Introduction}

With the acknowledgment of the global economic crisis in 2008, a new paradigm of sustainable development referred to as 'green growth' emerged, intensifying a transition to a 'green economy.' Green growth refers to "economic growth and development, while ensuring that natural assets continue to provide the resources and environmental services on which our well-being relies" (OECD 2011:9). The green economy should result in "improved human well-being and social equity, while significantly reducing environmental risks and ecological scarcities" (UNEP 2011:16). International organizations and institutions, multilateral and financial institutions, as well as environmental NGOs (ENGOs) heralded this transition through various initiatives, reports, strategies, plans, summits and public statements. Examples include: UNEP's Green economy initiative in 2008 (UNEP 2013), the OECD's Green growth: overcoming the crisis and beyond (2009), Europe's 2020 growth strategy (EC 2010) and the Rio+20 outcome document, The future we want (UNCSD 2012). All of these supported a conviction that building green economic sectors, through the economic valuation and inclusion of biophysical services, resources and products in the market, can successfully respond to the economic, financial and environmental crises of our times.

Based on this logic, in the past few years market systems have been extended to carbon, energy and diverse aspects of nonhuman nature in an attempt to build a global 'green infrastructure.' An exponential growth of previously established environmental governance policies can be observed (see for example REN21 2007; 2013 for the global growth of RES investments since 2008), while various innovations in the trading of 
carbon products and ecosystem services have also resulted (including $\mathrm{REDD}^{2}$ ). Political ecology literature is critical of efforts to 'green' capitalism in this way. It emphasizes that new accumulation avenues for capitalist expansion are opened up (Arsel and Büscher 2012; Bumpus and Liverman 2011; Fletcher 2012; Sullivan, 2013). One common thread is that crisis(es)-inspired neoliberal environmental policies can lead to new appropriations, dispossessions and undesirable environmental outcomes. A volume edited by Fairhead et al. on 'green grabbing' (2012) examines the appropriation of land and resources based on green credentials, indicating that green grabs tend to have profound effects on local livelihoods. ${ }^{3}$

This article provides insights into how green economies are built and what new appropriations and dispossessions they (might) entail. It examines the proliferation of photovoltaic projects in post-crisis Greece, and the building of an associated green economy in the country. As Apostolopoulou and Adams (2015) say and Hadjimihalis (2014) and Siamanta (2016) demonstrate, the penetration of private RES projects in the post-crisis era has led to green grabbing of land. ${ }^{4}$ A relatively undocumented aspect, however, is the appropriation of public and private financial resources for photovoltaics, with associated impacts on livelihoods and social equality. McCarthy et al. (2012) have also addressed the appropriation of government budgets and subsidies - what they call 'budget grabbing' - under 'virtual land grabs' for Jatropha cultivation for biofuel in Indonesia. Hadjimihalis (2014) discusses the appropriation of subsidies by wind park investors and the rents received by RES investors in Greece, in the context of its debt crisis.

In this case, public financial resources have been appropriated through indirect state subsidization (via feed-in tariffs) and a market 'bubble', and private money through green levies and other means, based on green and economic recovery credentials. Financial green grabbing through PVs (photovoltaics) in post-crisis Greece has been supported by a particular organized green energy discourse of economic recovery and climate protection. The article also argues that discourses justifying the green economy involve the complex interplay of disciplinary and neoliberal environmentalities seeking to motivate individuals to participate through individual investments, and by obtaining their consent for large projects.

In the first section I discuss the methods used, while in the second I explain photovoltaic investments made in Greece. I begin by discussing how a green economy/energy friendly alliance in the country formulated a particular green energy discourse between early 2009 and mid-2012, through a variety of discursive, institutional and other-non discursive practices. Then I discuss how the sector's backers employed particular arts of government combined with hegemonic narratives on the Greek economic crisis to construct 'green economy entrepreneurs' and 'green economy compliant subjects.' This discourse was materialized in the production of clean energy, but had socio-political implications, the grabbing of public and private financial resources. In the third section I discuss the important issues that arise from the Greek case.

\section{Methods}

This article is based on findings from a Foucauldian oriented discourse analysis, in depth semistructured interviews and the reviewing of a variety of sources of information. The analysis was based on Foucault's archaeological and genealogical enquiry into discourse (i.e. archaeology-plus-genealogy), while it drew on Foucault's concepts of 'biopower' and 'neoliberal and disciplinary governmentality', as developed by the end of his 1978-1979 lectures on The birth of biopolitics at the Collège de France (Foucault 2008[19781979]). ${ }^{5}$ Archaeology-plus-genealogy were used to illuminate the objects of knowledge created, the hidden rules of formation of these objects, the historical conditions of the existence of the discourse, how certain 'truths' concerning green energy were inserted into institutional and other non-discursive practices, and the

\footnotetext{
${ }^{2}$ Reducing Emissions from Deforestation and Forest Degradation. Investments in RES have been promoted at the global and European level as important green economy policies (e.g. EC 2010; UNCSD 2012; UNEP 2011).

${ }^{3}$ See also Corson et al. (eds.) 2013 for a newer volume on green grabbing.

${ }^{4}$ Apostolopoulou and Adams (2015) refer to land acquisition through the construction of RES projects in protected areas as combining elements of 'green' and 'un-green' grabbing. They suggest the latter is the appropriation of land and resources involving the exploitation and appropriation of protected natures, not predicated upon a green rhetoric.

${ }^{5}$ For 'archaeology' see Foucault (1965[1961]; 1970[1966]; 1972[1969]; 1973[1963]). For 'genealogy' see Foucault (1977[1975]; 1979[1976]). For the complementary use of archaeology and genealogy see for example Kendal and Wickham (1999).
} 
subjects constructed by the discourse. A genealogy charted the connections between discourse, institutions and mechanisms of domination, illuminating the power and institutional configurations involved in the construction of a particular regime of truth on green energy. ${ }^{6}$ The discourse analysis involved a collection of written, oral and audiovisual material:

1) speeches and statements by the Greek Prime Ministers and Ministers of Environment and Economics,

2) Laws, Ministerial Decisions, Law Bill Explanatory Statements, and reports and press releases by the former Ministry of Environment, Energy and Climate Change (aka YPEKA),

3) reports, guides, press releases, statements, official websites and Facebook profiles of large Greek ENGOs,

4) official websites and press releases of RES market bodies and statements by their key representatives,

5) television advertisements by banks and ENGOs, and

6) the Greek printed and electronic press. ${ }^{7}$

The findings presented here focus on the construction of a truth regime, subject formation and institutional and power configurations involved. Nineteen semi-structured interviews and two open discussions were conducted with key actors from the Ministry of YPEKA, public and market RES bodies, large ENGOs, large RES companies, small photovoltaic investors (i.e. domestic PV owners) and a political party (SYRIZA) between 2012 and 2015. Other sources of information reviewed included but were not limited to: Laws, governmental reports, official RES bulletins, license files for RES works, websites of RES companies, as well as the 2012 Memorandum of Understanding on Specific Policy Conditionality that the Greek government signed with the EU, the ECB and the IMF (called here, the troika).

\section{The case of photovoltaics in post-crisis Greece}

\section{A green energy discourse and a new truth regime}

Before the global economic crisis in 2008, RES were promoted in the country by large ENGOs, RES market bodies and on occasions by the state, mainly as weapons against climate change (see for example Oxi Allo Karbouno 2007). By the end of 2008 Greece had seen a small growth of RES, with it contributing only $4.3 \%$ to the country's energy needs in electrical energy and the installed photovoltaic capacity being $12 \mathrm{MW}$ (Hellenic Republic-YPEKA 2009). ${ }^{8}$ From early 2009 there was an explosion of discursive activity and institutional practices in Greece regarding RES, but set in a period of fiscal crisis with numerous changes of government to come. Two large Greek ENGOs - Greenpeace Greece and WWF Hellas - said RES and/or an energy revolution based on them, could provide thousands of green jobs, combat the economic crisis, and mitigate climate change. There were a variety of press releases, statements, scientific reports/assessments and social media posts making this case (e.g. Greenpeace 2009a,b; WWF Hellas 2009a,b). Other posts by Greenpeace Greece in 2009 emphasized the urgency for the turn to RES and citizen participation as "energy revolutionaries" (Greenpeace Greece 2015). In 2009, the Greek state instituted a special program for photovoltaics on roofs, by which households and small businesses could install them and produce green energy, with very beneficial feed-in tariffs (Joint Ministerial Decision 04/06/2009).

Later in 2009, the former Greek Prime Minister of the New Democracy government - Kostas Karamanlis - declared early elections, invoking the need for economic measures to combat the economic

\footnotetext{
${ }^{6}$ For more information on how the discourse analysis was conducted see Siamanta (2016).

${ }^{7}$ The Ministry is currently called the Ministry of Environment and Energy.

${ }^{8}$ Installed capacity is the maximum power a station can produce.
} 
crisis, which had begun to appear on the national and global political stage. During the 2009 pre-electoral campaigns, the candidate for Prime Minister from the opposition party PASOK, George Papandreou, announced that the way out of the economic crisis should include green growth. Papandreou referred to green growth in almost all of his pre-electoral speeches, while he frequently referred to the development of RES as way to instigate growth (e.g. Papandreou 2009a,b). He stated in Parliament that "Greece can become a pioneer in the great revolution of green growth" through, amongst other things, "the turn to RES" (Papandreou 2009c: online). The propagation of green growth continued after he became Prime Minister in 2009 (e.g. Papandreou 2010a; 2010b).

In 2010, following austerity measures and the emergence of a national deficit of $13.6 \%$ of GDP, the Prime Minister announced acceptance of an international financial support mechanism formulated by the troika. The Memoranda of Economic, Financial and Specific Policy Conditionality were signed in 2010. The narrative accompanying the support mechanism and the Memoranda was that the country was on the verge of collapse and needed deep fiscal and structural changes so as to avoid default (Papandreou 2010c,d). RES were not included in the Memoranda's reforms. However, given the financial crisis and government commitments, the government instituted the 'acceleration of the development of RES' through Law 3851/2010 about a month later. The Law characterised RES as an "upmost environmental and energy priority" for the country, it set national RES targets, and instituted very beneficial feed-in tariffs for PVs. Also, it simplified environmental regulations, and permitted the building of photovoltaic stations by farmers on their land. ${ }^{9}$ Minister of Environment Tina Birbili said the idea was to boost and reinforce the Greek economy through new jobs and investments totalling millions of Euros (see YPEKA 2010a,b). Shortly after, Birbili announced a green Plan of Developmental Interventions aiming to attract and implement investments of 44 billion Euros (US $\$ 46.7 \mathrm{bn}$ ) by 2015, with thousands of new jobs (see YPEKA 2010c). The key pillar of the Plan was the transition to a competitive low carbon economy that also addressed climate change, to include the expansion of RES projects. Later in 2010, the government instituted targets for photovoltaics through Ministerial Decision 19598/2010, namely 1,500 MW for 2014 and 2,200 MW for 2020, but with no limit for PVs on roofs. ${ }^{10}$

WWF Hellas and Greenpeace Greece continued to support wind parks and PVs based on similar claims to the government, through a set of scientific assessments/reports, guides, press releases, statements and social media posts (e.g. Greenpeace, 2010a; WWF Hellas and Athens Economic University 2010; WWF Hellas 2010). WWF Hellas promoted PVs on roofs as profitable investments. Market RES bodies said similar things in press bulletins, announcements and interviews in the media, stressing the role of RES in benefiting the Greek economy and the climate/'environment' (e.g. HARESP and HWEA 2011; Helapco 2010). Greek banks like Piraeus Bank and Eurobank, linked RES with competitiveness and other benefits (Eurobank 2012; Piraeus Bank 2010). Between 2009 and 2011 newspapers popularized the new policies and the availability of green loans for PVs and beneficial tariffs (e.g. TaNea 2009; ToVima 2010a). In late 2011, the EU Council agreed on a large scale photovoltaic project in Greece, called the Helios project. Its main purpose was the transport of energy produced through PVs in Greece to Germany and countries of Northern Europe, and to use the income generated for reducing Greece's debt (European Council 2011). The new Minister of Environment George Papaconstantinou talked of reducing the Greek debt by 20-25 billion Euros (US\$21.326.6bn) over 25 years (e.g. Papaconstantinou 2011).

In late 2011, following Papandreou's resignation, a transitional coalition government of PASOK, New Democracy and Popular Orthodoxy Rally was formed without elections. The partnership between PASOK and New Democracy - long term adversaries - was unprecedented. A second structural adjustment program and new Memoranda were formulated between the troika of funders and the coalition government, and entered into force in early 2012. ${ }^{11}$ The program and the Memoranda were again accompanied by a narrative of urgency, impending collapse and chaos, as well as a need for structural changes (e.g. Papadimos 2012a). The Memoranda included the completion of "the transposition and implementation of the renewable energy Directive", "the implementation of the renewable energy project 'Helios"', as well as "the reform of the

\footnotetext{
${ }^{9}$ The feed-in tariffs given for photovoltaics were at the time amongst the most favourable ones across Europe (Dusonchet and Telaretti 2010).

${ }^{10}$ This includes 500MW and 750MW for agricultural PVs, respectively.

${ }^{11}$ Popular Orthodox Rally left the government before the Parliament vote for the 2012 Memoranda.
} 
renewable energy support schemes such that they are more compatible with market developments and reduce pressures on public finances", including "measures for the development of wind and solar energy resources" (Greece Memorandum of Understanding on Specific Economic Policy Conditionality 2012: 764). Greece was tied down to structural reforms designed to strengthen its business environment and free market competition (ibid: 753-770, 755-766). After the new Memoranda, the Prime Minister Lucas Papadimos again promoted investments in RES as a national priority for similar reasons as before, with the 'Helios' project creating jobs and local growth (Papadimos 2012b). The Minister of Environment also supported RES and Helios (Papaconstantinou 2012). ${ }^{12}$

In mid 2012, with the fiscal crisis still ongoing, there was another transitional government and more elections. New Democracy, PASOK and the Democratic Left (aka DIMAR) formed a coalition. ${ }^{13}$ RES growth created a public RES deficit so the support framework was reformulated. The government advocated rationalization with more benefits for electricity consumers (Maniatis 2013). WWF Hellas and Greenpeace Greece, as well as RES market bodies, have continued to promote the RES growth mantra, highlighting the deficiencies of the coalition government's energy policies. A further coalition government in early 2015 (SYRIZA and Independent Greeks) advocated support to small and very small RES investors (Lafazanis 2015) and later the further expansion of RES under a new reformulated support mechanism for contributing to the fight against climate change (e.g. Skourletis 2016). ${ }^{14}$

It is clear that a green energy discourse prevailed between early 2009 and mid 2012: a heterogeneous ensemble of narratives, institutions, regulatory decisions, laws, administrative measures, expert/scientific statements and propositions (Foucault 1980:194). ${ }^{15}$ The discourse was that the development of private RES projects, and especially photovoltaics and wind farms, was linked to economic growth, climate change mitigation, and resolving Greece's fiscal crisis. The solution was inflows of capital from private RES investments leading to green jobs, and overcoming the country's dependence on lignite coal. The installation of photovoltaics on houses, businesses and plots would be profitable. A new truth regime was constructed, around exiting the crisis and fighting climate change, with citizen benefits. Turning to RES was necessary for the 'national interest' and the wellbeing of Greek citizens, and further afield through emissions reductions. In forming and producing this discourse a variety of actors aligned: the state, mainstream Greek ENGOs, RES market bodies, Greek banks and the mainstream mass media.

"Biopower" was exercised and focused on the management of the Greek population as a whole (Foucault 1979; 2008[1978-1979]). According to Foucault, it operates in "societies of control" (i.e. births, deaths, environments, reproduction, health) and through techniques of normalization. Biopower generates and controls life through the governance of populations, producing a new "social reality" that it is suggested, "already exists" (Lemke 2001:202). Entire populations can be managed and controlled through such a political technology, legitimising authority through creating a reality. By claiming that private RES investments (including photovoltaics) served to enhance the wellbeing and (economic) vitality of the Greek population, as well as the wellbeing of the climate and of the global and national 'environment', biopower was exercised.

\section{Shaping 'green' subjectivities}

When the size of the Greek deficit was announced in 2010, the economic crisis was seen as an unprecedented threat. 'Shock tactics' were employed, with the Prime Minister and the Minister of Economics portraying the country as a sinking ship, or as the sinking Titanic (see Papandreou 2010d; Tovima 2010b). Fear and confusion prevailed. The consequences of Greek debt were rendered as multiple and tragic, with structural measures essential to save the economy and avoid collapse and catastrophe (Greek Explanatory

\footnotetext{
12 The 'Helios project' was cancelled in late 2012 as it was not deemed economically viable by Germany due to the high cost of building energy transport networks, while it may be picked up again once this cost has dropped (Interview 1: YPEKA, RES Service, Athens, 03/07/2013).

${ }^{13}$ PASOK and New Democracy dominated the Greek political landscape since 1974 under a two-party system, which officially collapsed in the first elections of 2012. DIMAR left the government in 2013.

${ }^{14}$ The formation of the government of SYRIZA and of Independent Greeks after the first 2015 elections signified a historical change in the country, since a government with a leftist orientation was established for the first time.

${ }^{15}$ From mid 2012 and onwards the discourse was subject to reconfigurations to match the new environment.
} 
Statement 2010:1). Changes were necessary to avoid default and for the state to function, paying wages and pensions (Papandreou 2010c). At the same time, newly formulated hegemonic narratives accompanying the crisis and the Memoranda presented Greek citizens as 'irresponsible', 'lazy', 'corrupt', 'living beyond their abilities' and responsible for the debt (see for example Mylonas, 2014 on the hegemonic explanations of the crisis and especially for how these explanations were reproduced by the popular newspaper Ekathimerini). Such narratives blamed unaffordable public spending, citizens taking their pensions early, and an unproductive public sector. Greeks were embezzling money from the public sector through tax evasion and bribes. These narratives were promoted by Greek and foreign political leaders (Pangalos 2010) and were popularized by the Greek and foreign media (Mylonas 2014). Thus, according to the hegemonic discourse and narratives on the Greek economic crisis and bailout mechanism, Greece had to change, with a new collective consciousness and effort by everyone (Papandreou 2010c,d). Greek citizens had to become 'responsible citizens'; leaving aside their individual self-interest for 'the common good.' The common good was 'necessary' austerity measures and making the country an equal and worthy member of the EU. Disobedience and dissent with austerity were pathologized, citizens were rendered as selfish, atomists, irresponsible, or manipulated by the Left (Mylonas 2014 and Leontidou 2014 on how the Indignant Citizens' Movement was framed). As discussed in the previous section, private RES investments and particularly in PVs and wind farms were widely promoted as a way to instigate growth and exit the crisis and their expansion as for the 'national interest.' According to the hegemonic discourses and narratives, Greeks thus had an ethical responsibility to put aside personal interests to permit expansion of private RES works, for the 'national interest' and the greater good.

On the other hand, climate change was propagated by the green energy discourse as a serious global and national socio-ecological threat. Greenpeace and WWF Hellas advocated for action, and the Prime Minister George Papandreou said it was the "biggest modern threat" (Papandreou 2009c). According to the green energy discourse, as well as to accompanying hegemonic climate change narratives, Greece would suffer severely from climate change, with flooding of coastal areas, disease and the collapse of agriculture, tourism and the economy (Greenpeace 2010b; WWF Hellas 2009). ENGOs linked coal fired power stations to poor health in Greece and abroad (Greenpeace Greece 2015). Hence, 'an energy revolution' and the turn to RES were urgently needed. "The climate is in your hands" was WWF Hellas' popular campaign and slogan, and both WWF Hellas and Greenpeace said "you can save it" (Save the Climate 2009). Thus, each citizen had to show ethical responsibility and become an 'energy revolutionary' (Greenpeace 2009b) by demanding the country's turn to RES, making a photovoltaic investment and pressuring others to follow the same example (WWF Hellas 2010). Moreover, as these large ENGOs advocated, citizens should not get infected by 'not-inmy-backyard syndrome' (WWF Hellas 2010:183). People in the cities of Ptoleimaida and Kozani already had to put up with coal mines, power stations and pollution, so it was morally wrong for people elsewhere to be complaining about the installation of RES in their areas.

Here lies the operation of what Foucault describes as a "disciplinary governmentality" (Foucault 2008[1978-1979]) and particularly a "disciplinary environmentality" (Fletcher 2010, after Foucault 2008[1978-1979]). The internal disciplining of individuals insists on active participation in calculable environmentally-friendly behaviours. Foucault said 'governmentality' reflects 'the art of government', how power is exercised in social relations in order to formulate the 'conduct' of individuals. It is a distinctive modality for exercising power, understood as work 'at a distance' - governing oneself to governing others. Environmentality describes an application of governmentality in environmental arenas (see for example Agrawal 2005; Fletcher 2010; Li 2007). ${ }^{16}$ Disciplinary 'arts of government' sought to compel individuals to internalize these social and ethical norms due to fears of social deviance (i.e. to avoid accusations of egotism in the face of national need, and 'the environment') and to self-subjectify themselves as particular kinds of subjects, as 'responsible citizens' and 'environmental stewards' who would provide their consent to large private RES projects and all the changes in the Greek polity these would entail. Or, to proceed with individual small scale PV investments. Power here was enacted internally, through the production of a particular subject whose identity as a good citizen was connected with a set of specific RES-friendly activities. Such production

\footnotetext{
${ }^{16}$ I draw heavily on Fletcher's (2010) close reading of Foucault in theorizing the distinction between disciplinary and neoliberal environmentalities.
} 
involved the active participation of individuals in their self-disciplining, as well as the body as a site of selfsubjectification and production.

In parallel, a "neoliberal environmentality" (Fletcher (2010:173) after Foucault (2008[1978-1979])) also operated through the discourse by creating external economic incentive structures within which individuals, understood as self-interested rational actors, could be motivated to exhibit an appropriate photovoltaic-friendly behaviour through the manipulation of economic incentives. Greek individuals were incentivized to become autonomous entrepreneurs by investing in rooftop PVs, as well as on agricultural land and in PV parks. According to the green energy discourse, such investments would be profitable due to high feed-in tariffs. At the same time, according to the hegemonic discourse and narratives on the Greek economic crisis and the Memoranda, Greek citizens would face painful but necessary measures for combating the debt and a "new Odyssey" (Papandreou 2010d), while 'shock tactics' manipulated the fear and confusion that surrounded the crisis (e.g. loss of jobs, reduced incomes). The risk that a low or medium income citizen thus had to assess was whether he/she would be affected by the crisis in a significant way (i.e. reduced income, not able to cover living expenses) and whether an investment in photovoltaics would alter this situation by securing an (additional) monthly income for 20 or 25 years. In other words, individuals had to weigh the economic cost of building photovoltaics against the economic benefit from selling green energy to the state.

By 2011 the economic crisis was already being felt. These led individuals to self-subjectify themselves as 'rational economic actors', to make rational conscious choices and self-regulate their behaviour for their own individual interest. This is what Foucault (1988) calls 'technologies of self', whereby citizens are asked to take responsibility for securing their own wellbeing, turning risks into a question of 'self-care' (Lemke 2001), rather than for the common good. It was an individualization of economic risk, the making of a neoliberal citizen from below, rather than above. Indeed, as three citizens who installed domestic PVs in the AitoliaAkarnania Prefecture mentioned, they made these investments in order to secure an additional income (Interview 2, 3, 4). ${ }^{17}$ As a farmer stated:

We (the famers) have to take a gamble on our future. Our land is lying there idle, it is fertile but we cannot sell our grain. My children and grandchildren have to eat every day. My eldest son has lost his job working in the local government offices and the future of his child, my grandchild, is now uncertain...If I put photovoltaic panels on my land then the immediate future looks more secure...my family will go hungry if I don't act now...and do not adapt and take this huge risk. (quoted in Knight 2014:10-11)

The employment of crises and the 'shock doctrine' (Klein 2007) were not the only pivotal elements in the operation of these environmentalities. 'The spectacle of nature' (i.e. the mediation of social relationships and nature-society relationships through images, videos and media productions) was important for formulating the relationship between people and this green technology (Igoe 2010; Igoe et al. 2010). For example, a variety of images portraying photovoltaics on roofs and photovoltaic parks were included in newspaper articles, emphasizing their profitability (Ethnos 2011; Tovima 2010a). A television advertisement by WWF Hellas and Eurobank under the framework of WWF's campaign 'ECO $\underline{E}_{2}$ nomy' showed an individual dressed as a panda sunbathing and enjoying vacations, from energy-saving profits (EurobankGroup 2012). The WWF's 'ECO ${ }_{2}$ nomy' campaign was linked to a website which discussed, amongst other things, saving money from investing in domestic PVs and using the 'He.l.i.os' application for calculating how much money one can make (WWF Hellas 2012a).

The parallel employment of these disciplinary and neoliberal environmentalities was aimed at the formulation of individual and societal conduct, in relation to photovoltaic and RES projects. This involved consent to a series of changes in the Greek polity needed for making the expansion of private RES projects feasible, as well as some land grabbing for building RES stations. Local social relations required disciplining in such projects, as well as enlisting green energy entrepreneurs.

\footnotetext{
${ }^{17}$ Interview 2: Domestic PV owner, Aitolia-Akarnania, 08/07/2015. Interview 3: Domestic PV owner, Aitolia-Akarnania, 09/07/2015. Interview 4: Domestic PV owner, Aitolia-Akarnania, 17/08/2015.
} 


\section{'Green' expansion}

The result was a spectacular expansion of photovoltaics in the country in just a few years. ${ }^{18}$ But in 2010, the PASOK government abolished direct subsidization for photovoltaics (Law 3908/2011). Banks attained a pivotal role in the green expansion. Aspiring investors turned to newly formulated and advertised green loans for photovoltaic installations of different types. A plethora of green loans followed. By the end of 2012 two banks, Piraeus Bank and Eurobank, had issued 12,010 green loans for the development of photovoltaics on roofs, amounting to 216 million Euros (US\$230m) (Eurobank EFG 2012; Piraeus Bank 2013). Private companies, such as EDF-EN, Kopelouzos Group, ELPE-Larco and ENEL Green Power implemented the larger projects (RAE 2015a). As a consequence, the country reached its 2020 photovoltaic goals in 2013, seven years early (Ministerial Decision 19598/2010; OEM 2013). By April of 2015 the installed photovoltaic capacity jumped to 2,604 MW (Hellenic Republic 2009; OEM 2015a). In 2014 there were approximately 55,000 photovoltaic stations in the country out of which approximately 40,000 were domestic PVs, 2,500 were on agricultural land and 14,000 were PV parks (Helapco 2014).

The 'photovoltaics bubble' and the RES deficit: the appropriation of public and private funds

In parallel with the photovoltaic expansion in Greece, a great expansion of photovoltaics was also observed across Europe and globally. Solar panel prices dropped. This, along with the high feed-in tariffs given in 2010 for Greek photovoltaics, meant that profits rose for those entering the market. Back in 2010 the PASOK government also ensured that a photovoltaic investor who had signed a contract based on a particular feed-in tariff had the right to wait for 18 months before building the station (Interview 1; Law 3851/2010). This automatically translated into a huge interest by investors (Interview 1). They capitalized on the high tariffs and waited as long as they could for further de-escalation of prices, and thus a higher profit margin (ibid). But the PASOK government did not re-adjust the high feed-in tariffs as panel prices dropped. This reflected "the political decisions that had been made within the Ministry" (Interview 6). ${ }^{19}$ The government "let investors enjoy huge profits" (ibid) and large profits were made by those who "paid attention" (Interview 7), securing the high tariffs and selling large amounts of energy to the state. ${ }^{20}$ They were the larger companies who monitored the market and controlled the largest share of the installed photovoltaic capacity (RAE 2015a). For example, EDF-EN Hellas S.A. had a net profit of about 1 million Euros in 2011 and 2012 (US1.1m) from only 3 PV parks of about 9 MW (EDF-EN Hellas S.A. 2013).

Thus, a 'bubble' was created in the market which resulted in the generation of a deficit in the public RES Fund. This is a public fund maintained by the system manager (OEM) which provides the tariff payments for RES producers (Law 2773/1999). However, the energy supplier, the Public Power Company (PPC), buys this green energy from OEM at a lower price, the sale price of energy derived from conventional fuels (the limit value of the system). This difference is covered by the public RES Fund and is thus subsidized by the state (Interview 1). The deficit first appeared in 2010 and by the end of 2013 it reached 550 million Euros (US\$585m) (OEM 2014). It is worth mentioning that PVs on roofs played a very small part in the deficit, despite the high feed-in tariffs given for them in 2009. This is because, by March of 2013, the funds provided by the state for buying energy that had derived from PVs on roofs amounted only to $10 \%$ of the total funds provided for buying energy derived from all RES technologies (YPEKA 2013).

To reduce the RES deficit, PASOK and subsequent coalition governments took a number of measures. Initially, they all increased the Special Levy for Reducing Air Pollutant Emissions paid by electricity consumers through their electricity bills. From June 2010 until March 2014 there was an increase of 0.30 Euro/MWh for all consumers, to 26.3 Euro/MWh (US\$28) for domestic electricity consumers and to 30.89 Euro/MWh (US\$32.9) for small businesses (Ministerial Decision 22473/2006, 11484/2010; RAE Decision 175/2014). Under this Levy, Greek consumers paid about 2.8 billion Euros (US\$3m) from 2012 to October of

\footnotetext{
${ }^{18}$ A smaller but steady expansion of wind farms built by large (multinational) RES companies was also observed in postcrisis Greece (see Hellenic Republic-YPEKA 2009; OEM 2015a).

${ }^{19}$ Interview 6: YPEKA, RES Service, Athens, 03/06/2013.

${ }^{20}$ Interview 7: Hellenic Wind Energy Association (HWEA), Athens, 10/07/2013.
} 
2015 (OEM 2014; OEM 2015a). In 2012 the coalition government of PASOK and New Democracy instituted a Special Lignite Levy (see Law 4042/2012) which was finally set at 2.5 Euros/MWh (US\$2.6) charged to coal-generated electricity producers (effectively PPC which still holds the monopoly on coal fired electricity). Until June of 2013 the PPC - and Greeks paying for its electricity - paid almost 70 million Euros (US\$74.5m) to the RES Fund (OEM 2014). Lastly, on August of 2012 the New Democracy, PASOK and DIMAR coalition decided that $25 \%$ of the Levy given to the national Hellenic Broadcasting Corporation (HBC) should be channeled to the RES Fund instead (see Ministerial Decision 2303/16935/2012). Eventually the HBC was abolished to save costs, but there was also a charge of 4.24 Euro per month (US\$4.5) for electricity consumers (ibid). ${ }^{21}$ Until the abolition of the HBC, the RES Fund received 64 million Euros (US\$68m) (OEM 2014).

In summary, considerable private funds deriving mostly from domestic and small business electricity consumers were, and are, being appropriated by the state through these green levies for covering the RES deficit, and hence the large profits made by big RES producers, as well for paying RES producers. This has severely affected low and medium income citizens still facing austerity measures and now, new taxes. They are effectively paying millions of Euros to support the RES deficit and the further operation of the Greek green energy market. In 2013, every month, some 30,000 households had their electricity supply cut off due to their inability to pay increasing electricity prices during the rough economic climate (Elafros 2013).

The search for government revenue continued. In 2012, the New Democracy, PASOK and DIMAR coalition demanded exceptional contributions of $25 \%$ to $30 \%$ from photovoltaic producers based on their turnover from July 2012-July 2014 (Law 4093/2012). These contributions were for existing and new stations excluding solar panels on roofs. In the following year, they increased to 34\%-42\% (Law 4152/2013). Lastly, New Democracy and PASOK instituted mandatory repayments under the so-called 'New Deal' (Law 4254/2014). This involved a return of $20 \%$ of the 2013 revenue for photovoltaics of up to $100 \mathrm{KW}$ and $34 \%$ to $37.5 \%$ of the 2013 revenue for all other photovoltaic producers. Some 12,500 photovoltaic parks and 2,500 agricultural systems were affected. Rooftop installations were excluded, but took mandatory reductions (20\%$40 \%$ ) of the 'guaranteed' prices they had secured for 25 years. A $12 \%$ reduction of the previously guaranteed prices was implemented for agricultural photovoltaics of up to $100 \mathrm{~kW}$ and a $10-30 \%$ reduction for all other operating PVs. ${ }^{22}$

The appropriation of these private funds had severe implications for small and medium photovoltaic producers and especially the ones who had taken green loans. Exceptional contributions meant that "these people cannot pay their loans" (Interview 1) and that they are now facing foreclosures from the banks. To make matters worse, from early 2013 the system manager has been delaying payments to RES producers due to the RES deficit for over six months (ibid; OEM 2015b). Thus, in many cases producers were/are impelled to return revenues which they have never collected in the first place, suffered reduced incomes and new and/or increasing taxes, while still paying interest on loans. Low and medium income citizens who installed photovoltaics on roofs, built agricultural PVs and PV parks and took green loans were driven to impoverishment by tariff reductions, and the mandatory payments on the high tariffs they thought they had secured when they made solar investments (Interview 3, 4, 5).

On the contrary, larger PV investors appear to have 'survived' these measures and are now profitable. This is because as a key actor from TERNA Energy noted, there was still a profit margin due to the 2013 tariffs, despite the contributions requested by the state, with PVs breaking even in 4 years (Interview 8). ${ }^{23}$ Larger investors have economic margins, despite delayed payments and contributions/repayments, and are able to pull resources from elsewhere and/or withstand temporary losses. They are currently developing PV parks of substantial installed capacity under the new reduced tariffs of 2013, indicating that such large PV investments will continue to be profitable. EREN Hellas S.A. of the EREN Groupe is an example - they made

\footnotetext{
${ }^{21}$ The Hellenic Broadcasting Corporation or ERT, is state owned. It was abolished as part of austerity measures in June 2013, but its employees refused to stop broadcasting. The loss of satellite connections, protests, and court cases followed. Parliament voted to re-establish ERT and it began broadcasting again in 2015.

22 The government of PASOK, New Democracy (and Popular Orthodoxy Rally) also reduced the prices for new PVs in 2012. The next government (New Democracy, PASOK and DIMAR) did the same in 2012 and 2013, while blocking the licensing process for a period in 2012 and 2013.

${ }^{23}$ Interview 8: TERNA Energy, Athens, 03/09/2013.
} 
net profits of about 3.6 million Euros (US\$3.82m) in 2014 and 2015 from three large PV parks totaling 24MW (previously owned by EDF EN Hellas) (see EREN Hellas, S.A. 2016). As smaller PV investors are driven to bankruptcy, the large ones appear to be developing an oligopoly, buying PV parks and production licenses (e.g. ENEL Green Power). But new PV companies are reluctant to enter the market (Interview 9). ${ }^{24}$ Indeed, only two small companies have requested a government photovoltaic production license since 2013, for almost $4 \mathrm{MW}$ of installed power (RAE 2015b). Greek banks also appear to have benefited from the state's policies on photovoltaics. Not only have they increased their portfolios to include small businesses, professionals and private individuals, but they have profited from interest paid on loans to green photovoltaic projects. They also face the prospect of foreclosing some photovoltaic stations and private properties due to non-repayment. Profits were of course also made by PV installation and supplier companies and by extension by large (multinational) manufacturers of PV panels. For example, BIOSAR Energy S.A., a subsidiary of Ellaktor Group specialized in the construction and maintenance of PV arrays in Greece and other countries, made 12 million Euros in 2011 (BIOSAR Energy S.A. 2012), while BIG Solar, the largest supplier of PVs in Greece (most made by LG, Panasonic and Sharp), and supplier of other energy saving systems, had a net profit of about 17 million Euros (US\$18m) in 2011 and 2012 (BIG Solar S.A. 2013). ${ }^{25}$

\section{Discussion: lessons from the Greek PV case for the 'greening' of economies}

The construction of a green low carbon economy in Greece involved the appropriation of public and private financial resources by few large RES and PV installation and supplier companies, as well as multinational manufacturers of PV technology (by association). Capital was eventually accumulated by these large actors through a market 'bubble', ultimately funded by green levies, exceptional contributions/repayments and FIT reductions, dispossessing low and medium income citizens. The latter were domestic and small business electricity consumers, and those running domestic and small business PVs, agricultural PVs, and small PV arrays. Financial gain is being extracted directly from their personal income, suggesting 'green energy financial expropriation.' At the same time, low and medium income citizens who took out green loans are currently at the risk of default to Greek banks, potentially at risk of losing their assets (i.e. land, homes). This, along with significant impacts on local livelihoods from the grabbing of land for building RES stations (Siamanta 2016), suggests 'green energy poverty' has been engendered by the penetration of green energy in Greece.

Peck et al. (2010) claim that economic crisis periods are, amongst other things, moments of opportunism. The saga of PVs in Greece suggests several. On the one hand, a key actor from the Ministry of YPEKA mentioned that the country's energy policy is "only what interests want", referring to the large private energy companies in the country and the clientelistic relationships that characterize the interaction between the state and the private sector (Interview 6) ${ }^{26}$ He mentioned that the PASOK government promoted PVs and wind farms rather than other RES technologies due to these interests. Referring specifically to the RES measures included in the 2012 Memoranda he noted that "what the investors wanted were adopted, the authors [of the Memoranda] wanted to promote what the investors wanted." A key actor from SYRIZA also noted that before the 2012 Memoranda the government was collecting various requests for RES works by private interests and companies from around the country (Open discussion 1). ${ }^{27}$ As he mentioned, "for example, Vardinogiannis came and said I want to create a station here." ${ }^{28}$ He concluded that the Memoranda was "a stitching together" of all the powerful pre-existing requests and private interests regarding RES. These suggest that the PASOK government implemented beneficial regulations for PVs partly to favor large (multinational) private RES operators (RES producers, PV construction and installation companies, large

\footnotetext{
${ }^{24}$ Interview 9: Rokas-Iberdrola, Athens, 09/09/2013.

${ }^{25}$ Only a handful of Greek companies produced PVs in the post-crisis era. Initially they were profitable, but are now bankrupt/going bankrupt (Interview 7).

${ }^{26}$ Clientelism, the provision of material goods in return for electoral support, is a key feature of Greek political culture (e.g. Mouzelis 1986), with clientelistic relationships observed between the state and the private sector (Pagoulatos 2003).

${ }^{27}$ Open discussion 1: SYRIZA, Athens, 13/05/2013.

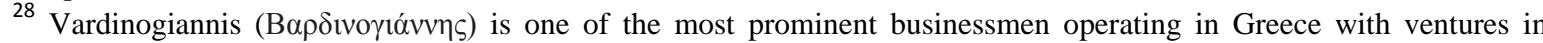
shipping, oil, broadcasting, and other fields.
} 
suppliers). This was done in an opportunistic, clientelistic fashion to maintain its power and hegemony in a politically unstable climate. The evidence is in the interviews and discussions, the clientelistic relationships between the state and the private sector, as well as in the way the PV 'bubble' was created and developed.

Similarly, it also appears that in an attempt to align the country with its mandatory RES measures, the PASOK and New Democracy government also backed the interests of the large private solar and wind park companies to maintain its position when the two-party system was under threat. The companies that made and continue to make large profits from the measures adopted in this period belong to the most prominent businessmen and millionaires in Greece, such as Kopelouzos, Latsis, Mpompolas Peristeris and Vardinogiannis. They include large PV producers and construction companies, as well as wind park companies directly subsidised by the governments while a severe economic crisis was in force (e.g. TERNA Energy, Rokas-Iberdrola).

It appears that the troika funders used the second structural adjustment program as, amongst other things, an opportunity for harmonizing the country with the further expansion of RES and specifically with solar and wind energy targets. However, the $2012 \mathrm{MoU}$ did not mention private or public RES technology development in Greece, while there was an explicit condition to privatize PPC (the Public Power Company) including PPC Renewables. This indicates the favoring of large multinational manufacturers that provide imported technology, as well as large RES companies who would produce energy and sell it to the state. Further, it appears that the troika used the second structural adjustment program as an opportunity to shift the economic cost of producing green energy away from the state and corporations and to pass it on society. This is evident in the explicit condition of the $2012 \mathrm{MoU}$ on reducing the RES pressure on public finances (i.e. the public RES deficit that had already developed). As Olli Rehn (the European Commissioner for Economic and Monetary Affairs and the Euro) said, the increase in the Special Levy for Reducing Air Pollutant Emissions decided on 10 January 2013 was a condition for paying the second installment of the second structural adjustment program loan to Greece (SYRIZA 2013).

All these suggest political opportunism in the rapid rollout of Greek photovoltaics: the management and manipulation of crises for benefiting the private sector, as well as the creation of opportunities for new fields of investment and avenues for capitalist accumulation and expansion, building on the Greek economic crisis and the discourse of climate change. Both were discursively constructed as disasters capable of having detrimental consequences for Greek citizens, and the Greek 'environment' and beyond, while private RES investments were one way to address and avert their effects. Through complex discursive mechanisms and arts of government, both these crises were folded into a new green accumulation frontier associated with green energy. Private (multinational) RES companies, PV construction and supplier companies and large multinational companies designing, manufacturing and supplying RES technology have been able to use RES investment as an accumulation strategy. The creation of new green accumulation frontiers can be understood in the context of the current economic and environmental crises. Over-accumulated capital seeks new investment opportunities and new 'fixes' for temporarily hindering the overproduction/overaccumulation crisis, while enabling ongoing accumulation. ${ }^{29}$

In parallel, as political ecology scholars acknowledge, the environmental crisis (including climate change) has become a major value creation and accumulation frontier for capitalism through market-based mechanisms and instruments such as carbon trading, payment for ecosystem services and biodiversity offsets (e.g. Sullivan 2013; Büscher and Fletcher 2014). The point here is that new avenues of accumulation are being invented. They increasingly involve the nonhuman world, new 'green'/conservation commodities and particular discursive framings of 'crises', 'nature' or 'the economy', to temporarily overcome the recent overaccumulation crisis and capitalism's environmental contradictions. ${ }^{30}$ In other words, new environmental 'conservation' frontiers are being invented to mediate capitalism's main contradictions. The same economic

\footnotetext{
${ }^{29}$ Over accumulation/overproduction crises are caused by what Marx (1976[1867]) identifies as the contradiction between the forces of production (i.e. a combination of labour and infrastructure) and the relations of production (i.e. the social system supporting capitalism).

${ }^{30}$ O'Connor (1998:165) describes the second contradiction of capitalism as "the way that the combined power of capitalist production relations and productive forces self-destruct by impairing or destroying rather than reproducing the conditions necessary to their own reproduction."
} 
expansion that impels these contradictions provides opportunities for continued accumulation. Green energy serves as a 'fix' for both these crises. On the one hand, it serves as a 'spatio-temporal fix' (Harvey 2003; 2005). On the other, it serves as an 'environmental fix' (Castree 2008): temporarily addressing the second contradiction of capitalism and achieving a sustained economic growth. This, of course, further subjects nonhuman nature to capital accumulation. In the Greek PV case, particular forms of 'life' (i.e. the Greek population as concerned environmentalists and rational economic actors) and 'nature' (the Greek environment with its sunshine and wind) were crucial. Critical geographers raise similar concerns when examining the accumulation and environmental change resulting from carbon markets and carbon offsetting (e.g. Arsel and Büscher 2012; Böhm and Dabhi 2009; Bumpus and Liverman 2008, 2011; Fletcher 2012).

The construction and operation of this green market and financial green grabbing was attained through direct state intervention. Neoliberalism is a state-led project (e.g. Castree, 2010; Harvey, 2005). Yet, the parallel operation of a disciplinary and a neoliberal environmentality - involving narratives of national and individual financial ruin and a climate apocalypse - were necessary for creating green market-disciplined individuals, and what Goldman (2001) calls 'eco-rational' subjects (with 'eco' referring to economic and ecological rational actors). Complex disciplinary and neoliberal arts of government were necessary for creating particular instrumentalist and economic rationalities around RES, as well as specific visions of environmental protection through them, reconfiguring existing values, beliefs and identities and enrolling human subjects in this new green economy as normalised green citizens and green entrepreneurs. The making of green energy entrepreneurs through environmentality is an example of 'the conduct of carbon conduct' (Patterson and Stripple 2010:345), in which individuals are disciplined into governing their own emissionproducing activities, either directly or indirectly through 'offsetting.' It also shows how new mechanisms of normalization and subjectification, involving creaing fears for one's wealth, lifestyle, livelihood and life (and with economic incentives linked directly to one's immediate wellbeing), are used for enlisting individuals in new green markets and economies. However, as Fairhead et al. (2012) highlight and as this case demonstrates, not everyone becomes disciplined as a neoliberal subject in these ways. Indeed, significant resistance is occurring in the country to both the green grabbing described in this article and the penetration of other RES technologies and associated land grabbing (see for example Pan-Cretan Network Against Industrial RES 2015). This contrasts sharply with the self-subjectification of individuals as 'green subjects' through the exercise of biopower.

\section{Conclusion}

What happened in Greece is not an isolated case. Acquisitions of financial resources for producing green energy through RES are happening in other countries. For example, in Germany and in the United Kingdom, private financial resources are being appropriated through green levies on electricity bills (see DECC 2013; Renewable Energy Resources Act-EEG 2014). In Spain, large state subsidies were given for photovoltaics (by 2009 the total annual cost was 26 billion Euros [US\$27.6bn] per year) and 'a bubble' and a tariff deficit were also created (del Rio and Mir-Artigues 2014). These indicate that the acquisition of public and private financial resources is an important aspect of building green economies and of the emerging order of green grabs in developed countries in particular, with significant impacts on livelihoods. Further research is thus required concerning its particular mechanisms, processes and socio-political implications.

This article has reiterated criticisms of 'the green economy' that it is 'business as usual' and tightens the grip of neoliberal capitalism. Building green economies involves the complex interplay of disciplinary and neoliberal environmentalities seeking to formulate green market-compliant citizens, and green market entrepreneurs. The associated 'green grabbing' also involves the appropriation of public and private financial resources that redraw and reinforce economic inequality. Given the increasing recognition of adverse implications of 'green policies' for human and nonhuman nature (e.g. Corson et al. 2013; Lohmann 2009), there is a need for other approaches to be deployed. Finding alternatives to 'the green economy', however, requires not only articulating dissent and rupture, but also creative engagement with marginalized knowledges and the imagination. 


\section{References}

Agrawal, A. 2005. Environmentality: technologies of government and the making of subjects. Durham: Duke University Press.

Apostolopoulou, E. and W.M. Adams. 2015. Neoliberal capitalism and conservation in the post-crisis era: the dialectics of 'green' and 'un-green' grabbing in Greece and the UK. Antipode 47(1):15-35.

Arsel, M. and B. Büscher. 2012. Nature $^{\mathrm{TM}}$ Inc.: changes and continuities in neoliberal conservation and market-based environmental policy. Development and Change 43(1):53-78.

Benjaminsen, T.A. and I. Bryceson. 2012. Conservation, green/blue grabbing and accumulation by dispossession in Tanzania. Journal of Peasant Studies 39(2): 335-355. Researchgate

BIG SOLAR S.A. 2013. Balance sheet for 2012. [accessed 10 September 2015]. http://www.bigsolar.gr/content/files/bigsolar_isologismos_2013.pdf.

BIOSAR S.A. 2012. Balance Sheet for 2011. [accessed 10 September 2015]. http://contentmcdn.feed.gr/pegasus/Multimedia/pdf/2011_id5756329.pdf.

Böhm, S. and S. Dabhi (eds.) 2009. Upsetting the offset: the political economy of carbon markets. London: Mayfly Books.

Bumpus, A. and D.L. Liverman. 2008. Accumulation by decarbonization and the governance of carbon offsets. Economic Geography 84(2):127-155.

Bumpus, A. and D.L. Liverman. 2011. Carbon colonialism? Offsets, greenhouses gas reductions, and sustainable development. In Peet R., P. Robbins and M.J. Watts (eds.) Global political ecology. London: Routledge. Pp. 203-224.

Castree, N. 2008. Neoliberalising nature: the logics of deregulation and reregulation. Environment and Planning A 40(1): 131-152. Researchgate

Castree, N. 2010. Neoliberalism and the biophysical environment: a synthesis and evaluation of the research. Environment and Society: Advances in Research 1(1):5-45.

Corson, C., K.I. MacDonald and B. Neimark. 2013. Grabbing green: markets, environmental governance and the materialization of natural capital. Human Geography 6(1): 1-15. Researchgate

DECC. 2013. Estimated impacts of energy and climate change policies on energy prices and bills. London: Department of Energy, Climate Change and Development. [Accessed 15 August 2015] https://www.gov.uk/government/uploads/system/uploads/attachment_data/file/172923/130326__Price_and_Bill_Impacts_Report_Final.pdf.

De Angelis, M. 2001. Marx and primitive accumulation: the continuous character of capital's 'enclosures'. The Commoner 2.

del Rio, P. and P. Mir-Artigues. 2014. A cautionary tale: Spain's solar PV investment bubble. International Institute for Sustainable Development and the Development Research Centre of the Council.

Dusonchet, L. and E. Telaretti. 2010. Economic analysis of different supporting policies for the production of electrical energy by solar photovoltaics in Western European Union countries. Energy Policy 38(7): 3297-3308.

EC. 2010. Communication from the Commission EUROPE 2020: a strategy for smart, sustainable and inclusive growth. Brussels, 3 March.

EDF-EN Hellas S.A. 2013. Financial data [accessed 8 August 2015]. http://www.eenhellas.gr/financial\%20data.htm (in Greek).

Elafros, G. 2013. 30,000 electricity cut offs per month from PPC. Kathimerini, 7 April. [accessed 10 January 2015]. http://www.kathimerini.gr (in Greek).

EREN Hellas S.A. 2015. Financial data. [accessed 10 November 2016]. http://www.eren.gr/index.php/GR/2016-02-16-09-27-08/2016-02-16-09-27-39 (in Greek).

Ethnos. 2011. PVs: income from the sun with zero risk. [accessed 15 June 2013 ]. http://www.ethnos.gr/epaggelmatikes_eukairies/arthro/fotoboltaika_eisodima_apo_ton_ilio_me_miden iko_risko-59284966/ (in Greek).

EurobankGroup. 2012. Eurobank WWF Program Eco ${ }_{2}$ nomy. [accessed 10 August 2015]. https://www.youtube.com/watch?v=Nz4QP0dcMUM (in Greek). 
Eurobank EFG. 2012. Annual report 2012. Athens, Eurobank EFG. [accessed 18 August 2015]. http://www.eurobank.gr/ (in Greek).

European Council. 2011. Euro Summit Statement. Brussels, 26 October. [accessed 8 August 2015]. http://www.consilium.europa.eu/uedocs/cms_data/docs/pressdata/en/ec/125644.pdf.

Fairhead, J., M. Leach and I. Scoones. 2012. Green grabbing: a new appropriation of nature? The Journal of Peasant Studies 39(2):237-261.

Fletcher, R. 2010. Neoliberal environmentality: towards a poststructural political ecology of the conservation debate. Conservation and Society 8(3):171-181.

Fletcher, R. 2012. Capitalizing on chaos: climate change and disaster capitalism. ephemera 12 (1/2): 97-112.

Foucault, M. 1965[1961]. Madness and civilization: a history of insanity in the age of reason. (trans.) Howard R. New York: Pantheon.

Foucault, M. 1970[1966]. The order of things: an archaeology of the human sciences. (trans.) Sheridan-Smith A.M. London: Tavistock.

Foucault, M. 1972[1969]. The archaeology of knowledge and the discourse on language. (trans.) A.M. Sheridan-Smith. New York: Pantheon Books.

Foucault, M. 1973[1963]. The birth of the clinic: an archaeology of medical perception. (trans.) SheridanSmith A.M. London: Tavistock.

Foucault, M. 1977[1975]. Discipline and punish: the birth of the prison. (trans.) Sheridan-Smith A.M. New York: Vintage Books.

Foucault, M. 1979[1976]. The history of sexuality, vol. 1: an introduction. (trans.) Hurley R. Harmondsworth: Penguin.

Foucault, M. 1980. The confession of the flesh. In Gordon, C. (ed.) Power/knowledge. Selected interviews and other writings 1972-1977. London: Harvester. Pp. 194-228.

Foucault, M. 1988. Technologies of the self. In Martin L.H., H. Gutman, and P.H. Hutton (eds.) Technologies of the self: a seminar with Michel Foucault. London: Tavistock. Pp.16-49.

Foucault, M. 2008[1978-1979]. The birth of biopolitics: lectures at the Collège de France 1978-1979 (trans.) Burchell G. Basingstoke: Palgrave Macmillan.

GARESP and HWEA. 2011. The discrediting of RES reinforces the anti-developmental climate. Press Bulletin, 26 May.

Goldman, M. 2001. Constructing an environmental state: eco-governmentality and other transnational practices of a 'green' World Bank. Social Problems 48(4):499-523.

Greece Memorandum of Understanding on Specific Economic Policy Conditionality. 2012. Government Gazette A' 28/14.02.2012:729-778.

Greek Explanatory Statement. 2010. Explanatory Statement for the Law Bill 'Measures for the Implementation of the Support Mechanism of the Greek Economy from the Member-States of the Eurozone and the International Monetary Fund. [accessed 10 April 2012]. http://www.hellenicparliament.gr/ (in Greek).

Greenpeace Greece. 2009a. Green growth and new employment positions. Athens: Greenpeace (in Greek).

Greenpeace Greece. 2009b. Energy revolution. Now! [accessed 10 August 2015] http://www.greenpeace.org/greece/el/testHub/ER/news/energy-revolution/ (in Greek).

Greenpeace Greece. 2010a. A new course for RES in Greece. [accessed 10 August 2015]. http://www.greenpeace.org/greece/el/news/118508/118517/new-re-legislation/ (in Greek).

Greenpeace Greece. 2010b. 'The problem'. http://www.greenpeace.org/greece/el/campaigns/climatechange/to_provlima/ (accessed 10/08/2015).

Greenpeace Greece. 2015. Facebook timeline for the years 2009-2012. [accessed 10 August 2015]. https://www.facebook.com/greenpeace.gr?fref=ts (in Greek).

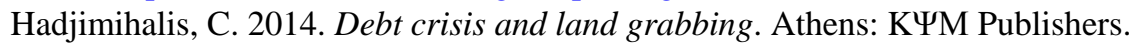

$\begin{array}{lllrrr}\text { Helapco. } & 2010 . & \text { Announcement. } & \text { [accessed } & 10 & \text { July }\end{array}$ http://helapco.gr/pdf/anakoinosi_sef\%20_FIN_f 100610.pdf (in Greek).

Helapco. 2014. Statistical data for the photovoltaics market in 2013-last update 10/06/2014. Athens. [accessed 8 August 2015]. http://helapco.gr/wp-content/uploads/pv-stats_greece_2013_June14.pdf (in Greek). 
Hellenic Republic-YPEKA. 2009. $5^{\text {th }}$ national report regarding the penetration level of Renewable Energy Resources 2010 (Article 3 of Directive 2001/77/EC). Athens: YPEKA (in Greek).

Igoe, J. 2010. The spectacle of nature in the global economy of appearances: anthropological engagements with the spectacular mediations of transnational conservation. Critique of Anthropology 30(4):375397.

Joint Ministerial Decision 04.06.2009. Special program for developing photovoltaic systems on building facilities and especially on terraces and roofs of buildings. Government Gazette $B^{\prime}$ 1079/4.06.2009:13717-13724 (in Greek).

Kendall, G. and G. Wickham. 1999. Using Foucault's methods. London: Sage.

Klein, N. 2007. The shock doctrine: the Rise of disaster capitalism. New York: Picador.

Lafazanis, P. 2015. Parliament speech during the policy statements, 10.02.2012 [accessed 10 November 2016] http://www.ypeka.gr/Default.aspx?tabid=785\&sni\%5B524\%5D=3495\&language=el-GR (in Greek).

Lemke, T. 2001. The birth of biopolitics-Michel Foucault's lecture at the College de France on neoliberal governmentality. Economy and Society 30(2):190-207.

Leontidou, L. 2014. The crisis and its discourses: quasi-Orientalist attacks on Mediterranean urban spontaneity, informality and joie de vivre. City 18(4-5):551-562.

Law 2773/1999. Liberation of the electricity market-Regulation of energy policy issues and other provisions. Government Gazette A' 286/22.12.1999:5081-5100 (in Greek).

Law. 3851/2010. Accelerating the development of Renewable Energy Resources to deal with climate change and other regulations addressing issues under the authority of the Ministry of Environment, Energy and Climate Change. Government Gazette A' 85/04.06.2010:1753-1780 (in Greek).

Law. 3908/2011. Reinforcement of private investments for economic development, entrepreneurship and peripheral cohesion. Government Gazette A' 8/01.01.2011:39-54 (in Greek).

Law. 4042/2012. Criminal protection of the environment-Harmonization with Directive 2008/99/ECProduction and management framework for waste-Harmonization with Directive 2008/98/ECRegulation of issues of Ministry of Environment, Energy and Climate Change. Government Gazette A' 24/13.02.2012:231-274 (in Greek).

Law. 4093/2012. Approval of medium term fiscal strategy framework 2013-2016-Urgent implementation measures of Law 4046/2012 and of the Medium Term Fiscal Strategy Framework 2013-2016. Government Gazette A' 222/12.11.2012:5525-5648 (in Greek).

Law. 4152/2013. Urgent implementation measures of Laws 4046/2012, 4093/2012 and 4127/2013. Government Gazette A' 107/09.05.2013:1571-1622 (in Greek).

Law. 4254/2014. Support and growth measures for the Greek economy in the framework of the implementation of Law 4046/2012 and other provisions. Government Gazette A' 85/07.04.2014:13831490 (in Greek).

Murray Li, T. 2007. The will to improve: governmentality, development, and the practice of politics. Durham: Duke University Press.

Mylonas, Y. (2014) Crisis, austerity and opposition in mainstream media discourses of Greece. Critical Discourse Studies 11(3):301-321.

Lohmann, L. 2009. Climate as investment. Development and Change 40(6):1063-1083.

Marx, K. 1976[1867]. Capital: a critique of political economy, volume 1. (trans.) Fowkes B. Harmondsworth, London: Penguin Books.

McCarthy, J.F., J.A.C. Vel and S. Affif. 2012. Trajectories of land acquisition and enclosure: development schemes, virtual land grabs, and green acquisitions in Indonesia's outer islands. The Journal of Peasant Studies 39(2): 521-549.

Ministerial Decision 22473/2006. Determining the Special Levy of article 40 par. 3, sect. c' of Law 27273/1999 to 0.30 Euro/MWh. Government Gazette B' 1702/21.11.2006:23219-23220 (in Greek).

Ministerial Decision. 11484/2010. Determining the Special Levy of article 40 par. 3, sect. c' of Law 2773/1999 to 5.57 Euro/MWh. Government Gazette B' 815/10.06.2010:13033-13034 (in Greek). 
Ministerial Decision. 19598/2010. Decision for the intended analogy of installed power and distribution in time between the various Renewable Energy Resources technologies. Government Gazette B' 1630/11.10.2010:25751-25752 (in Greek).

Ministerial Decision. 2303/16935/2012. Defining a contribution percentage for H.B.C S.A. of art. 14 of Law 1730/1987, which is a resource of the Special Fund of art.40 of Law 2773/1999. Government Gazette B' 2317/10.08.2012:38358-38359 (in Greek).

OECD. 2009. Green growth: overcoming the crisis and beyond. Paris: OECD Publishing.

OECD. 2011. Towards green growth. Paris: OECD Publishing.

OEM. 2013. Monthly bulletin of special RES \& CHP account. January, Athens: OEM S.A. [accessed 20 August 08 2015]. http://www.lagie.gr/ (in Greek).

OEM. 2014. Monthly bulletin of special RES \& CHP account. January, Athens: OEM S.A. [accessed 20 august 2015]. http://www.lagie.gr/ (in Greek).

OEM. 2015a. Monthly bulletin of special RES \& CHP account. November, Athens: OEM S.A. [accessed 10 January 2016]. http://www.lagie.gr/ (in Greek).

OEM. 2015b. Completion of full payment for energy produced through RES March 2015. [accessed 15 August 2015]. http://www.lagie.gr/anakoinoseis/anakoinoseis/anakoinosi/article/1122/ (in Greek).

Oxi allo karbouno. 2007. Solutions exist. [accessed $10 \quad$ July 2012]. http://www.ohiallokarvouno.gr/index.php?option=com_content\&view=category\&layout=blog\&id=67 \&Itemid=104 (in Greek).

Pangalos, T. 2010. We embezzled [money] together. [accessed 10 August 2015].

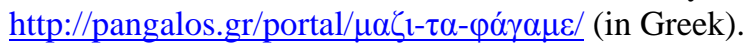

Papadimos, L. 2012a. Address by the Prime Minister Papadimos Loucas. [accessed 10 August 2015]. https://www.youtube.com/watch?v=F7IvfI0Y87s (in Greek).

Papadimos, L. 2012b. Greeting of Prime Minister at the all-day event of YPEKA and of the European Commission on Energy with the theme: RES and development of infrastructures in the Southeast Europe \& the Helios Project. [accessed 10 August 2015]. http://www.voreini.gr/politics/ $\pi \alpha \pi \alpha \delta \eta \dot{\mu o \varsigma-\eta-}$

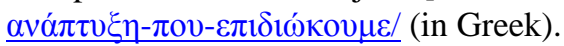

Papaconstantinou, G. 2011. Common interview of Minister of YPEKA George Papaconstantinou and of Executive Director of the International Energy Agency Maria Van Der Hoever during the presentation of the official report 'Energy policies of the countries of the IEA: Greece 2011'. [accessed 10/10/2015]. http://ypeka.gr/Default.aspx?tabid=389\&sni[524]=1343\&language=el-GR (in Greek).

Papaconstantinou, G. 2012. Speech at the all-day event of YPEKA and of the European Commission 'RES and the development of infrastructures in Southeast Europe \& the Helios Project. [accessed 10 August 2015]. http://ypeka.gr/Default.aspx?tabid=389\&sni[524]=1754\&language=el-GR (in Greek).

Papandreou, G. 2009a. Speech - Let's go together. [accessed 12 July 2015]. http://archive.papandreou.gr/ (in Greek).

Papandreou, G. 2009b. Speech - Let's go together to win our common future. [accessed 12 July 2015]. http://archive.papandreou.gr/ (in Greek).

Papandreou, G. 2009c. Policy statements by the Prime Minister George Papandreou. [accessed 12 July 2015]. https://www.youtube.com/watch?v=6seHyTQwD6w (in Greek).

Papandreou, G. 2010a. Speech delivered by Prime Minister George A. Papandreou at the Delhi Sustainable Development Summit 2010. [accessed 12 July 2015]. http://archive.papandreou.gr/.

Papandreou, G. 2010b. Greeting of Prime Minister at the event 'Building the future' for sustainable buildings and green growth. [accessed 12 July 2015]. http://archive.papandreou.gr/ (in Greek).

Papandreou, G. 2010c. Parliament Speech 'Everyone is called upon take up their responsibilities'. [accessed 12 July 2015]. http://archive.papandreou.gr/ (in Greek).

Papandreou, G. 2010d. Address by the Prime Minister George Papandreou from Kastelorizo. [accessed 12 November 2014]. http://archive.papandreou.gr/ (in Greek).

Pan-Cretan Network Against Industrial RES. 2015. Home. [accessed 10 February 2015]. https://sites.google.com/site/pankretiodiktyoagonakatavape/ (in Greek). 
Patterson, M. and J. Stripple. 2010. My Space: governing individual's carbon emissions. Environment and Planning D: Society and Space 28(2):341-362.

Piraeus Bank. 2010. Green banking-advertisement-Piraeus Bank. [accessed 10 August 2015]. https://www.youtube.com/watch?v=puVSSXVgphI (in Greek).

Piraeus Bank. 2013. Annual report 2012. Athens: Piraeus Bank. [accessed 17 August 2015]. http://www.piraeusbankgroup.com/ (in Greek).

RAE. 2015a. Licenses files-Registry files of licenses for energy production through RES [Excel]. [accessed 14 July 2015]. http://www.rae.gr/categories_new/renewable_power/licence/licence_files/data1.csp (in Greek).

RAE. 2015b. Files of requests for issuing a production license for electric energy by RES and CHP. [accessed 14 July 2015]. http://www.rae.gr/site/system/docs/registry/ape sithia.csp?viewMode=normal (in Greek).

RAE Decision 175/2014. Concerning the numerical values of the coefficients of the sharing methodology of the Special Levy of article 13 par. 2, sect. c' of Law 4001/2011, as stands. Government Gazette B' 816/02.04.2014:12631-12638 (in Greek).

REN21. 2007. Renewables 2007 global status report. Paris: REN21 Secretariat.

REN21. 2013. Renewables 2013 global status report. Paris: REN21 Secretariat.

Renewable Energy Resources Act-EEG. 2014. Act on the development of Renewable Energy Resources. Berlin: German Bundestag.

Save the Climate. 2009. Save the Climate [accessed 20 January 2011]. http://www.mazigiatoklima.gr/mazi.php (in Greek).

Siamanta, Z.C. 2016. Greening energy production in post-crisis Greece: a political ecology analysis of economic crisis, 'the green economy' and the neoliberalisation of nature. Ph.D. dissertation. London: Birkbeck University of London.

Skourletis, P. 2016. Press bulletin, Athens. 11 September. [accessed 10 Nomvember 2016]. http://www.ypeka.gr/Default.aspx?tabid=389\&sni[524]=4422\&language=el-GR (in Greek).

Sullivan, S. 2013b. Banking nature? The spectacular financialisation of environmental conservation. Antipode 45(1): 198-217.

SYRIZA. 2013. With the instruction of troika the increase of the special contribution for RES in PPC's bills. It was a condition for paying out the second instalment - Reply of Olli Rehn to Nikos Xountis. [accessed 10 August 2015]. http://www.syn.gr/gr/keimeno.php?id=34178 (in Greek).

Tanea. 2009. Our country needs a realistic long-term plan. [accessed 10 August 2012]. http://www.tanea.gr/printed/tanea/article?premium=1\&d=20090112\&aid=11184881 (in Greek).

Tovima. 2010a. Photovoltaics on roofs: they are profitable [accessed 10 August 2012].

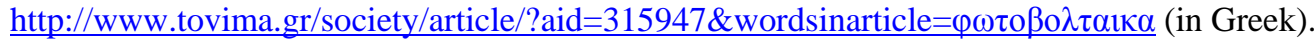

Tovima. 2010b. 'We will take additional measures if necessary', says Papaconstaninou from Brussels. [accessed 15 March 2013]. http://www.tovima.gr/finance/article/?aid=315381 (in Greek).

UNCSD. 2012. The future we want. UNCSD, New York: United Nations General Assembly.

UNEP. 2011. Towards a green economy: pathways towards sustainable development and poverty eradication. Nairobi: UNEP.

UNEP. 2013. Green economy initiative- about GEI. [accessed 14 April 2013]. http://www.unep.org/greeneconomy/AboutGEI/WhatisGEI/tabid/29784/Default.aspx.

WWF Hellas. 2009a. The green economy secures three million employment positions. http://climate.wwf.gr/index.php?option=com_content\&task=view\&id=164 [accessed 10 August 2015] (in Greek).

WWF Hellas. 2009b. No hope for the climate from the economic recovery programs [accessed 10 August 2015]. http://climate.wwf.gr/index.php?option=com_content\&task=view\&id=156(in Greek).

WWF Hellas. 2010. Guide for the environment: Renewable Energy Resources [accessed 10 August 2015]. http://www.wwf.gr/images/pdfs/WWF-Odigos-gia-to-perivallon-APE.pdf (in Greek).

WWF Hellas. 2012a. Eco ${ }_{2}$ nomy-saving ways - helios. [accessed 10 August 2012]. http://www.wwf.gr/economy/ways.html (in Greek). 
WWF Hellas and Athens Economy University. 2010. Green measures in Greece: cost/benefit analysis from the implementation of a series of promotion measures of Renewable Energy Resources (RES) and energy saving. Athens: WWF Hellas (in Greek).

YPEKA. 2010a. Speech of the Minister at the Parliament Plenary. Press Bulletin. [accessed 10 June 2012]. http://ypeka.gr/Default.aspx?tabid=389\&sni[524]=321\&language=el-GR (in Greek).

YPEKA, 2010b. Press Bulletin: The Law Bill on RES was voted by the Parliament Plenary. [accessed 10 June 2012]. http://ypeka.gr/Default.aspx?tabid=389\&sni[524]=334\&language=el-GR (in Greek).

YPEKA. 2010c. The program of developmental interventions. Press Bulletin. [accessed 10 July 2014] http://ypeka.gr/Default.aspx?tabid=389\&sni[524]=459\&language=el-GR (in Greek).

YPEKA. 2013. YPEKA's report on the photovoltaic installations of the program of developing photovoltaic systems on roofs. Athens: YPEKA. [accessed 10 August 2015]. http://www.ypeka.gr/Default.aspx?tabid=389\&sni\%5B524\%5D=2403\&language=el-GR (in Greek). 